\title{
Networks of the Chinese Community in Milan
}

\author{
Deborah De Luca
}

\section{(2) OpenEdition \\ Journals}

Electronic version

URL: https://journals.openedition.org/remi/2016

DOI: $10.4000 /$ remi.2016

ISSN: $1777-5418$

\section{Publisher}

Université de Poitiers

\section{Printed version}

Date of publication: 1 December 2004

Number of pages: $29-48$

ISBN: 2-911627-38-5

ISSN: 0765-0752

\section{Electronic reference}

Deborah De Luca, "Networks of the Chinese Community in Milan", Revue européenne des migrations internationales [Online], vol. 20 - n³ | 2004, Online since 25 September 2008, connection on 14 April 2022. URL: http://journals.openedition.org/remi/2016 ; DOI: https://doi.org/10.4000/remi.2016

This text was automatically generated on 14 April 2022

(c) Université de Poitiers 


\title{
Networks of the Chinese Community in Milan
}

\author{
Deborah De Luca
}

\section{Introduction}

1 The dichotomy between individual and social structure (or society) has been the object of a lot of important theories which, in sociology, began with Weber and Durkheim. The concept of social network could be useful to make these two poles interact. Nevertheless, even in the different researches and theories that refer to this concept, it's possible to distinguish between the ones that assign the main role to the network as a structure that impose constraints to the nodes (the individuals) and the others that underline the ability of a person to manipulate and take advantage of his or her personal links.

2 The boundaries existing in a specific situation are even more adverse for an immigrant, who arrives in a new context he/she doesn't know the rules and the opportunities of. The only possibility of achieving his/her goals is to rely on the strong ties that are at hand. The emphasis on kinship and friendship relations is particularly evident in the case of Chinese immigrants who consider the guanxi (privileged relations that have to be carefully cultivated and maintained) as a primary need for the success of their immigration project. Unfortunately, nowadays the economical situation is so difficult and the newcomers are so numerous that the intra-community (or the family) ties can hardly guarantee either the adequate means to start an entrepreneurial career or the possibility of making money within it. There are various strategies to change this situation, but they all pass through the creation, if not of stronger at least of weaker bonds with the natives.

3 In this paper, I intend to describe the methodology used in my research and then an example of another method, which could be useful in migration studies.

4 I will then give a definition of social networks and a short overview of some theoretical contributions that proved significant in my study of the Chinese community in Milan. 
5 In the follow parts I will focus on immigration and on the various ways of conceiving integration with or within the local population, explaining why network analysis is more relevant than other approaches. In addition to that, I will expose the dynamic situation of the Chinese in Milan, showing the intra- and inter-community ties in the ' 80 s and in the ' 90 s, and afterwards making clear some differences among particularly significant ego (or family) networks.

\section{Methods of collecting network data in migration studies}

6 The study about the Chinese community in Milan represents the empirical part of this work; it has been conducted in October 2002 within the frame of a wider research on ethnic entrepreneurship (Chiesi, Zucchetti, 2003). The aim of this research was to understand which ethnic groups were more relevant, in which economical sectors and what was peculiar of their entrepreneurial model.

7 The two main groups turned out to be the Egyptians in the building industry and the Chinese in the clothes manufacture, import-export and in the leather goods workshops. The in-depth analysis by means of qualitative interviews to the entrepreneurs revealed that it was not really possible to talk about an ethnic economy in the Egyptian group ; on the contrary this was the case of the Chinese ${ }^{1}$.

8 I conducted sixteen semi-structured interviews. Nine of them were made with entrepreneurs in the clothes or leather manufacture, three with owners of clothes import-export shops, two with entrepreneurs that were diversifying in different sectors and one with a Chinese woman that had a clothes workshop and is currently working (but also acting informally) as a broker between Chinese and Italian institutions in different situations. The last interview was with an Italian dependent of the "Italia-Cina" Association. Furthermore, the analysis continued with an open interview to an Italian accountant who works in the area where Chinese has always lived and worked (Canonica-Sarpi) and has mainly Chinese customers, an interview with an Italian person that is living in the same area, another one to a teacher in the primary school in Monza Padova area and, finally, the observation of a protest of the local committee ${ }^{2}$ that asked for police and health service in order to have the hygienic and legal situation of the import-export shops located in the area controlled.

9 Apart from my own research, I also collected documents from other researches dealing with the transformation and growth of the Chinese community and with the integration process, including some projects started by a primary school with a high density of Chinese pupils (Farina et al. 1997 ; Ceccagno, 1998; Murer, 2001 ; Cologna \& Mancini, 2000 ; Cologna, 2002a, 2002b).

During my interviews I have built the ego-network of Chinese entrepreneurs, focusing on the economical sphere, so as on the social one, which were both overlapping in many cases. Because of my ignorance of Chinese language I had problems of comprehension, and I had to face the interviewee's lack of trust and confidence. Therefore, it has been arduous to gain detailed information about the individuals that composed the personal network.

11 On the contrary, the documentary research has given a quite clear definition of the general network of the community in the 80s and 90s through the ties among the most 
common economical and social positions. Thank to this kind of network, one can give a picture of the situation in a specific moment and understand what have been the changes compared with the previous period. On the other hand, the most significant ego-networks that have been rebuilt are more adequate to explain the individual dynamic strategies that the actor is developing in order to achieve his/her goals and improve the social and economical situation of his/her family.

The qualitative interview method was chosen because the research group considered it as the best one to reconstruct the path followed by the immigrants from China to Milan and from the first job to the actual entrepreneurial condition. In another research (Cologna, 2002a), structured questionnaires have been employed, but even though the target was the same (Chinese entrepreneurs in Milan), the aim was different, because the focus was on the integration process and the questions were about opinions, not about the figures that had been involved in the migration project.

Anyway, it's important to underline that networks (ego-centred or containing the whole group) and network properties (density, multiplicity, centrality, etc.) can be surveyed not only with in-depth interviews and direct observation, and with quantitative methods too. With these methods it is easier to use networks to explain a phenomenon and not only as a useful metaphor to describe the existing situation.

14 As a concrete example of how it's possible to study the role of networks with a quantitative method, I will make use of a national research about the role of social networks in the entrepreneurial performance I have participated in 2002. A structured questionnaire was proposed to the entrepreneurs covering several areas of their life (economical, political, associative, and emotional). In every field, some name-eliciting questions led to identify a link with somebody. Later, for all the persons quoted during the interview, the entrepreneur was asked to describe them (job and place of living) and to specify the kind of link he had with them (when and how they met frequency of communication and degree of confidence). Finally, the interviewed person had to specify who, among these persons, knew any of the others and whom.

In my opinion this kind of interview could be fruitfully used in migration studies for many reasons, exploring the entire path from the emigration to the present. First, it's possible to understand clearly the transformations during time and the changing role of the different persons in the network. Second, it's possible to measure the real weight of family and friends in the migration process. Third, the degree of integration will be suggested by the frequency and depth of relations with members of the local population. Fourth, these kinds of data can give a better idea of the areas in which there is more connectedness among the community members compared with outgroup members and vice versa.

of course, the whole research project should combine quantitative network data collection with in-depth interviews. At the beginning, the latter are necessary to explore the field and adjust the questionnaire to the specific case study, while the quantitative results can emphasize distinctive network patterns in some areas and could lead to further qualitative analysis in order to clarify aspects that were not included in the questionnaire. 


\section{Social networks}

17 "Social networks analysis is grounded in the observation that social actors are interdependent and that the links among them have important consequences for every individual. For example, links among actors permit the flow of material goods, information, affect, power, influence, social support and social control. They provide individuals with opportunities and, at the same time, potential constraints on their behaviour" (Freeman, 2000). Among all the existing definitions of social network (for a general review, see Piselli, 1995), I have chosen this one because it considers all the different resources that can be transferred within the network and explains with simple words the polarity that I am trying to point out.

The limits imposed to the action of single actors by the network structure have been studied with formal methods by some sociologists (see, for example, Marsden \& Lin, 1982). Even if it's difficult to deny that situations impose constraints upon action, there is not a real determination. Actors are able to manipulate networks to reach certain aims. This is shown in the research of Granovetter (1973: 1974) about the strength of weak ties in finding a new job, especially for qualified jobs. On the contrary, Grieco (1987) insists on the central role of strong ties. These different results can be expounded considering that weak and strong ties are fruitful in distinct contexts. Weak ties provide access to information and resources that are unknown to the actor, and that can open a range of opportunities that are undisclosed to the actor's family and friends. This is the main function that weak ties have : they are a bridge between ego and distant others. Therefore, a link with a distant (affectively, but also socially) person gives more opportunities to find a more qualified job. On the other hand, strong ties, as Grieco shows, allow the migration of the individual, providing him with support, hospitality and even a job. Of course, the kind of job is related to the status of the family and to the jobs its members have actual access to. These two theories are very important for migration studies. Even if only the second author deals explicitly with migration chains, also the first one gives a relevant contribution to understand the path through economical and social integration that immigrants follow.

In some theories, the strength of ties is connected to the motivation for action (Lin, 2001). Strong ties are better for expressive action, that is to say maintaining resources and giving support to individuals that are often structurally equivalent ${ }^{3}$, while weak ties are more indicated for instrumental action because there is the possibility to interact with people in other positions in the structure. The motivation for action can also depend on the network structure. "Networks with many structural holes (the absence of ties within networks) produce entrepreneurial or competitive motivation, whereas those with cohesive or dense ties produce cooperative motives and may engender a sense of community among network members" (Kadushin, 2002: 77). I will show that in the Chinese community case study both the theories are partially true, but there are some exceptions to them.

Finally, the theory of brokers (Boissevain, 1974 ; Gould \& Fernandez, 1989; Coleman, 1990) helps to better understand the situation of the case study. Brokers are the people who occupy a structural position that links pair of otherwise unconnected actors. They manipulate their ties in order to receive profit, which is not necessarily economic, but also can be prestige or influence. Brokers act in many different ways : they represent the community (or a person within it) in the relations with an external subject (for example, a bank or the police); they give advice or information to relatives or friends 
who know little of the local context; they coordinate different activities within the community (like renting houses or matching jobs offer and demand) and they can also decide or give suggestions in disputes or discussions within the community. Brokers belong either to the in-group or to the out-group and the more the brokers connect the different communities, the more the process of integration goes a step further.

21 After this short introduction of the main contributions that social network theories give to the argument of this paper, I will continue with migration and the just mentioned process of integration in the host society.

\section{Migration, integration and networks}

Since the beginning of XX century, the phenomenon of migration has attracted the attention of social researchers, who have defined different models concerning the integration of the newcomers. The first model, the "melting pot", was meant to be a social process that would have redefined the belonging and identity system of people, creating a new identity for everybody. In reality, this has never happened. What was realized in the end can be named a "transmuting pot", where every immigrant has adapted to what America asked him/her to become. The ineffective model of the "melting pot" was substituted by the idea of the "salad bowl", a society where all the components should melt, but keep their own specificity and identity. Parallel to this proposal, which is not yet realized, another model has emerged: the "radical multiculturalism", which is the ultimate defence of one's own specificity and traditions that at any cost must survive, even through complete closure to others (Berti, 2000). This last model represents well the opinion that some Italians have towards the Chinese population in Italy, especially in the area of Milan where this community is more visible and is more "threatening" the identity of the Milanese.

Beside the problem of newcomers' integration, the role of social network in the immigration process has often been studied.

24 A work where it's possible to find a link between migration, job chains and networks, apart from the one of Grieco discussed in the first paragraph, is a study of selfemployment rates of Asian immigrant groups (Fernandez \& Kim, 1998). According to the authors, job opportunities readily available to immigrants who have been excluded from mainstream occupations are those which generally do not require direct competition with native-born workers. This is the case of the clothes manufacture and leather goods workshops of Chinese in Milan, because these sectors require highintensity work and give a low margin of profit. Another business opportunity is goods and services for ethnic customers, which is also quite developed by Chinese. Selfemployment, even if marginal, may look more attractive than the available low-skilled, low-wage service jobs in the labour market, but to accomplish entrepreneurial aspiration it is required the ability to mobilize the necessary resources to business preparation and operation. In addition to their personal human capital, they need to mobilize their social network in order to get economic support, information and lowcost workers.

The entrepreneurial desire is one of the main features that is common for chinese immigrants, wherever the host country (or town) is. The Chinese communities seem to be organized around their firms in the sense that the economic and social life is closely linked to the entrepreneurship. This is the essential preliminary remark to the 
definition of Chinese immigration as a Diaspora (Ma Mung, 1992, 1994 ; Campani, 1994). An immigrant community can be considered a Diaspora when people coming from the same country develop a transnational identity, when the migration is directed to many destinations and when there are constant relations among the different migration poles. The poles represent the nodes of the network and the links among the ties allow the exchange of goods, money, information, support, persons. The Chinese community of Milan is more strongly linked with France and the Netherlands, where other communities from the same Chinese region are established and families are sometimes partly in Italy and partly in the other countries. As far as the host country is concerned, every node of the Diaspora should be structurally equivalent, because the immigrant can find the same conditions through the diffusion of entrepreneurship and the presence of members of the same kinship or village. The movement from one pole to the other depend on economic and political conditions, like better opportunities to open a small firm or temporary laws that regularize clandestine immigrants who demonstrate to have a job. For example, a lot of Chinese arrived in Italy from other European countries during the ' 90 s in coincidence with this kind of laws. The main limit of the Diaspora concept is that it can be now acceptable because the integration process is still at an early stage (most of the Chinese immigrants arrived in the host countries in the '80s and '90s), but what will happen in the next generations? Will Chinese born in the host countries still have a distinct identity that will make them feel more similar to the other Chinese in Europe than to French, Dutch or Italian? In my opinion, it is in this dynamic process that the individual has the chance to manipulate his/her personal network so as to reach the desired degree of integration.

While the types of integration (melting pot, salad bowl, radical multiculturalism) described earlier attribute to the immigrant minorities a passive role according to the degree of tolerance they are exposed to and consider them as a whole, the use of social networks widen the range of individual possibilities. The combination of strong and weak ties, the density of the network and the multiplicity of the links influence the degrees of freedom and modify the path through integration. Of course, this is related to the economical position of the family and the chance of leading a successful activity within the ethnic firms ${ }^{4}$, to the influence of local institutions and educational agencies and to the human capital owned by the individual. The combination of these factors and the actor's ability to manipulate his/her network can lead to different results in terms of transforming or maintaining the ethnic identity.

In the next paragraph, I will expose some new aspects and recent transformations of the Chinese community in Milan that my work has enlightened.

\section{The Chinese communitiy in Milan in the '80s}

I will now retrace the recent history of the Chinese population in Milan. Before starting, one should remember that the timing is an approximation, because changes are a permanent process, and individual experiences vary a lot. But, on the whole, we are dealing with tendencies which have already been underlined by other authors (Farina et al. 1997 ; Cologna, 2002a).

The Chinese started to arrive in Milan in the '30s. The first came from Qingtian, a district of the Zhejiang region, in the South of China. Even nowadays, most of the 
Chinese living in Milan come from Zhejiang and, in particular, from the area around Wenzhou.

In the middle of the ' 80 s, only 500 Chinese were regular residents in Milan (Cologna, 2002b). Most of them were employed in three sectors: restaurants, clothes manufactures and leather goods workshops. During that period, restaurants experienced important increase, and, all sectors had good performances. Through their good results, the Chinese community raised funds and loans were collected not only among relatives, but also from people originating from the same village. In that way, when new immigrants arrived, they worked in the businesses of relatives or friends for many hours per day. Sometimes, they even lived in the workshop, together with other workers. After 2 to 3 years the economic status and living conditions usually improved. Then, they could legalize their position, thanks to recurring legalization laws, and bring their own family to Italy : their wives, if they were not yet in Milan, and their children, who usually stayed in China during the initial hard period. The ties that existed in the community in the ' 80 s are described in the following graph:

Graph. 1 : Network of a typical path through autonomous job and (relative) integration in the ' $80 \mathrm{~s}^{1}$

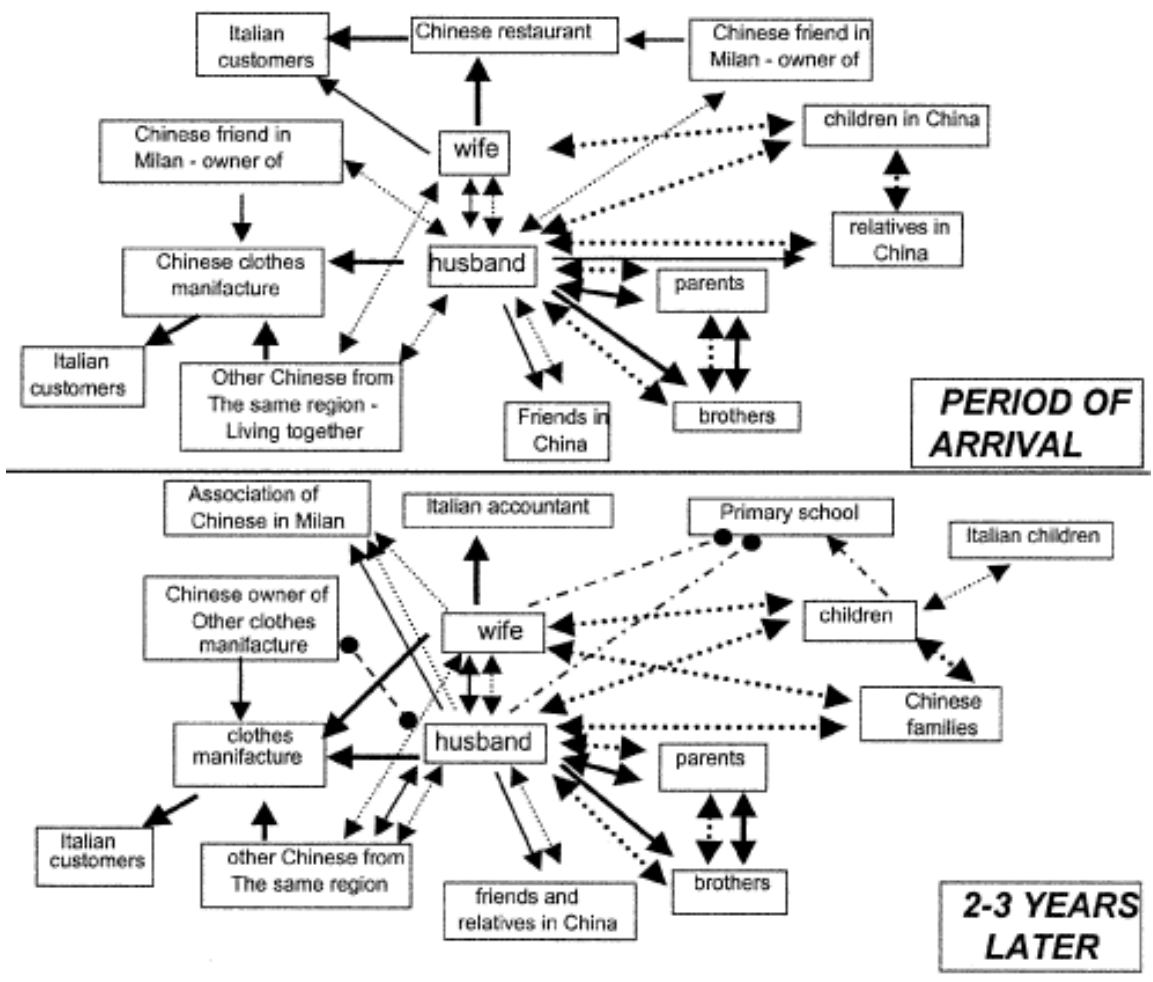

Unbroken line = economic tie

Small dots line $=$ informal social tie (expressive)

Stroke-dot line $=$ formal social tie (institutional)

Edge $=$ direction of the relation

Arrow $=$ cooperative relation

Small ball = competitive relation (conflict)

Thickness (unbroken line) $=$ degree of confidence

Thickness (small dots line) $=$ degree of $($ inter $)$ dependence

1 -In this network and in the next ones, some lines among the actors are omitted in order to have an understandable graph. The main actors, of whom I consider all the ties, are "husband" and "wife". In the family, some ties between the wife and other relatives are omitted because the Chinese society is mainly patriarchal and kinship mainly follows the male line. 
cases, family ties played a central role, economically and socially, together with Chinese friends and possibly other relatives in Milan (high multiplicity). These ties were almost always present. When they arrived in Milan, married couples were working in different sectors: one in a restaurant and the other one in a leather or clothes workshop. If the wife's job was in a restaurant, she usually worked as waitress, while men were more often employed as kitchen helpers. This gave the woman higher possibility and motivation of learning Italian, because she was in contact with customers. This ability was very important when the couple opened their own workshop and they had to interact with Italian customers. In that case, the new entrepreneurs could ask the help of an interpreter (friend or relative), but if the wife's knowledge of the language was adequate, it was her that dealt with the customers, playing an important economic role, which gave her more authority and independence, compared to her previous status in China (Ceccagno, 1998). Contacts with customers was one of the few relations that Chinese entrepreneurs had with the Italians, because all their workers were usually Chinese, relatives or people at an earlier stage of their immigrant's career.

Another group of Italians that was important for their economic life were the accountants, who helped them to cope with Italian laws and solved many of their problems, in some cases together with a lawyer. That Chinese economic network was very important in everyday life and, consequently, the frequency of contacts was very high and the actual dependence and trust between accountant and entrepreneur was quite strong. But trust was hardly ever accompanied by friendship.

The situation was different when the problems concerned other Chinese or the family. Before referring to Italian institutions or persons, the entrepreneur sought the advice of the Association of Chinese in Milan, which, until the end of the '90s, was the only Association that existed in the community. The Association, which included the eldest, most influent and long-term immigrants, was the main authority within the community and the official link with Italian institutions.

Beside the economic sphere, other relations with Italians took place when children went to school. Nowadays, as well as in the ' 80 s, children are very important in the migration strategy of the family (Farina et al. 1997 ; Ceccagno, 1997 ; Cologna, 2002b) because, through attending an Italian school, they are able, after a couple of years, to understand and speak Italian quite well. Thanks to this ability, they are often involved, as linguistic go-between for their parents, in different situations that require interaction with Italians. The intermediation role given to children implies that they deal with matters usually pertaining to their parents (like police controls of the firm, relatives' illness or funerals, etc.). Furthermore, parents give a lot of importance to their children's school achievement, as they consider that school is the main institution to transmit education and culture (more than the family itself). Therefore, they put a lot of pressure on their children because of their high expectations. The relation with teachers is not easy either, not only as a consequence of linguistic problems, but also because the Chinese teachers are stricter and give a lot of homework, which the Italian teachers don't do. So, if the children's results are not brilliant, tensions between parents and teachers appear (Ceccagno, 1997). In recent years, an attempt to solve these problems with Chinese parents has been made by a Milanese school (See next point).

Revue européenne des migrations internationales, vol. 20 - n³ | 2004 


\section{The Chinese community in the ' 90 s : Canonica-Sarpi and Monza-Padova}

At the end of 2002, approximately 12650 Chinese people were living in Milan ${ }^{5}$.

Graph. 2 : Map of Milan

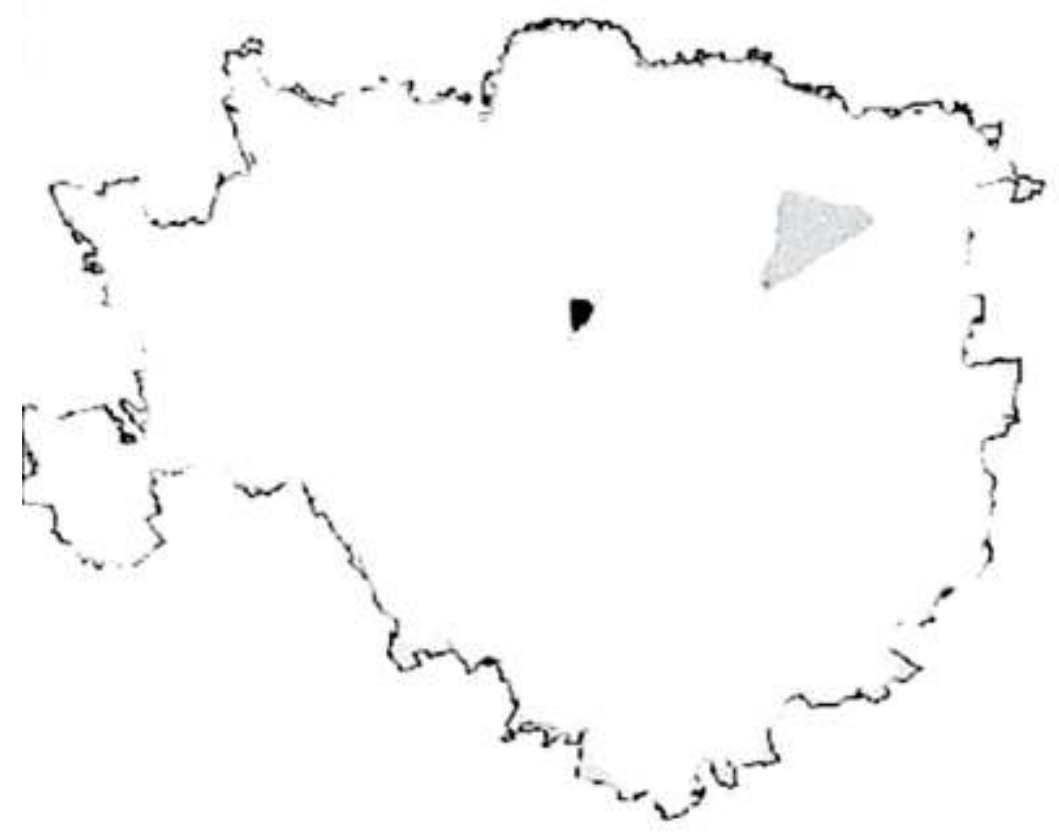

Black area $=$ Canonica Sarpi - Grey area $=$ Monza Padova

The very large increase of the Chinese population in the last years has caused big problems inside the community networks. The in-group difference of status has weakened the ties among people coming from the same village. Solidarity is strong only among close family members. The general economic situation concurs to increase status differences, and undermines communitarian solidarity.

The two main sectors, in which Chinese are employed and have their firms, leather and clothes manufactures, are not expanding anymore. Conversely, they are facing a crisis that reduces the already low margins of profit. Being a workshop owner is more a question of survival than a sign of success. The activity that produces the best results is trade with China, which includes different kind of goods, especially shoes and clothes. The customers of these shops are usually go-between of other nationalities, but also Chinese, because the economic crisis has obliged many newcomers to accept jobs that would have been refused until some years ago. That has increased the economic ties and interdependence of family members; sometimes strong ties are the only ones that give a chance of improving one's condition. They are therefore both expressive and instrumental, in partial contradiction with the theory of Lin (2001) that tends to separate these two functions. For example, as it is shown in Graph. 2, the brother who acts as a go-between is a is strongly dependent in his career on the shop owner that, because of their kinship, can favour him (lowering prices or giving him the best quality goods), thus increasing his possibilities to make money and find another job. 


\section{The Canonica Sarpi area} Canonica ${ }^{6}$, where now some streets are entirely occupied by this kind of shops. Such change has not only made the Chinese more visible in the area, compared to the time when workshops were only located in the basements of the houses. It also created problems of local traffic and road conditions. In addition to this, Sarpi Canonica has become the centre of social life for all the Chinese living in Milan. Shops that address to Chinese customers are concentrated in this area : a library, a video store, hairdressers and, of course, Chinese food and clothes stores. Everything that people need in everyday life can be found there. Other groups of immigrants and some Italians are also regular patrons of these cheap shops. This success, the increased visibility of the Chinese and the traffic and bad road conditions (this is, officially, the main reason), has provoked a reaction from local Italian shopkeepers and part of the local Italian population. It has given life to a committee, named Vivisarpi, that very frequently calls for the police to control the Chinese and has asked the local administration to force the Chinese import-export shops to move to another area. Cohabitation between Chinese shop owners and Italians seems more and more difficult.

Competition has increased, on the one hand because of the conflict with part of the Italian population and authorities, which did not exist in the '80s. But it also results from the growing number of immigrants and a difficult economic situation, which made competition harder, among people who own the same kind of firm. Divisions within the Chinese community are stronger than in the past. This partly contradicts the theory of Kadushin (2002) that I have exposed in the first point : dense network are not always cooperative. Everybody knows everybody else. They meet for official events (like marriages, annual parties, associative meetings, etc.), but competition is present and causes intra-community problems.

These struggles are evident also in the multiplication of more specific and fragmented economic associations : from 1999 on, 11 new associations have been founded, but the only one that has generally recognized authority, especially with Italian institutions, is the ancient Association of Chinese in Milan. 


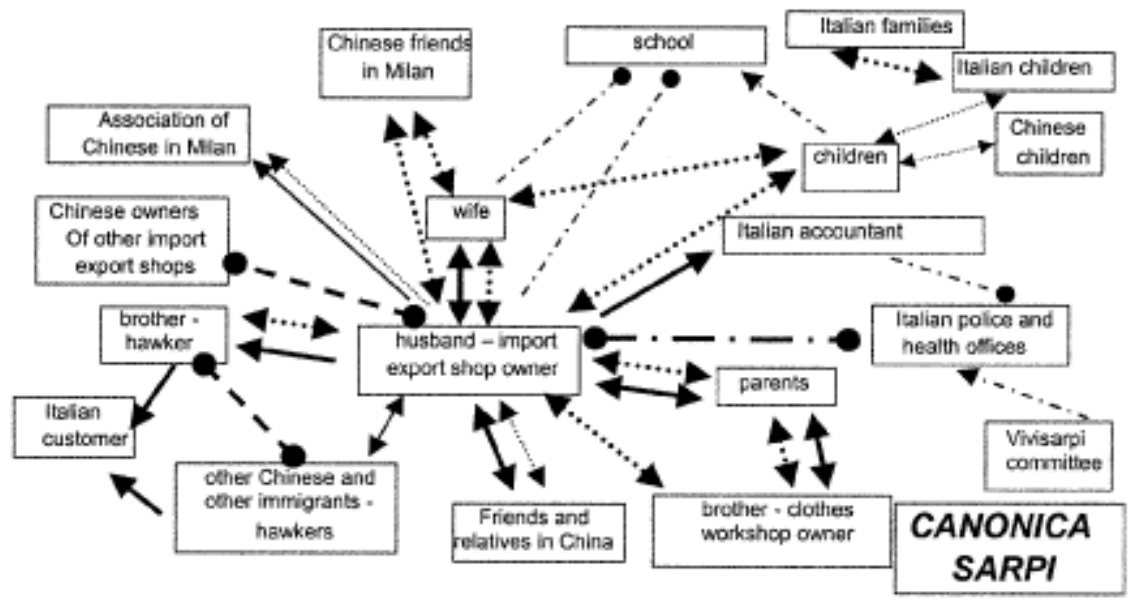

Unbroken line = economic tie

Small dots line $=$ informal social tie (expressive)

Stroke-dot line $=$ formal social tie (institutional)

Edge $=$ direction of the relation

Arrow $=$ cooperative relation

Small ball = competitive relation (conflict)

Thickness (unbroken line) $=$ degree of confidence

Thickness (small dots line) $=$ degree of (inter) dependence

2 -This network desribes the main activities and people present in the area and it's very similar to the one of family which I have interviewed two members of.

\section{The Monza Padova area}

This area has developed around one of the main communication axis of the town. Traditionally populated by people from Southern Italy, it has recently been occupied by immigrants, attracted by the low cost of houses and workshops. In fact, immigrants represent $12 \%$ of the entire local population, which is the highest percentage in Milan. In this area, Chinese are the second largest foreign nationality ${ }^{7}$ (they were 1760 in 2000), after Philippines nationals. The Chinese are not concentrated in a few streets; they tend to live in apartments or basements where it is possible to install a workshop. Leather and clothes manufactures are their most important businesses, together with restaurants and take-a ways.

Apart from occasional inspections made by the police, the relations with Italians are much better than in Canonica Sarpi. This has also been shown by a research among Italians and Chinese shopkeepers. Italian still have a positive stereotype about the Chinese : compared to other groups of immigrants, they are considered more quiet and dedicated to work. Relations are not generally seen as problematic, even if there are some exceptions (Cologna, 2002a).

A specific project to facilitate the integration of Chinese children and their families has been developed for some years by the primary school of the area, where Chinese pupils represented, until a couple of years ago, the biggest proportion of immigrants in the school. Today, they are around one third of the foreigners. Because the Chinese living in the area are newcomers, or people that have not had a great success in their migration career (Ceccagno, 1997), parents put even higher expectations than usual in the achievement of their children. The school has decided to improve the relations and 
condition of the children and their families in different ways. First, professional linguistic go-between facilitate contacts between parents and teachers without giving the pupils too much responsibility. Second, Chinese families (especially mothers) are more involved in school life and participate in meetings with teachers and Italian parents in order to discuss the children's socio-cultural integration. Third, a cultural exchange between Italian and Chinese children has been promoted: they study together both at Italians' and Chinese's homes, in order to directly experience different ways of talking, thinking and behaving. Fourth an optional course of Chinese language and culture, for both Italians and Chinese children, has been organized. Moreover, teachers receive a specific know how that should improve their relations with Chinese pupils. Unfortunately, neither cultural exchange nor Chinese courses has yet started during last year. There are two reasons: the reduction of specific funding has prevented the school from having some teachers full time on the project (some teachers do it in their spare time); Chinese pupils are less and less numerous, and, beside, they were more and more frequently born here, so they already learn Italian at nursery-school (immigration in the area becomes more stable and rooted). Anyway, initiatives in favour of multiculturalism and integration proceed as much as possible. official documents are also printed in Chinese and linguistic go-between are still used during the meeting between teachers and parents.

In this case, though with the restrictions due to economic difficulties, an institution behaves as an intermediate, fostering the integration of the Chinese minority. This voluntary action is shown in graph. 4 :

Even if the ties between Chinese and Italian families are not particularly strong, at least the relationship is positive. This is the first important link that can improve the situation of the Chinese community, but for the moment, only from a social point of view. A better integration can have positive effects on the performance of Chinese pupils, and maybe they can get better results in their studies. If this condition is fulfilled, it will be possible for them to widen their professional opportunities, compared to those, which were available for their parents, thus improving the economic situation of the family. 


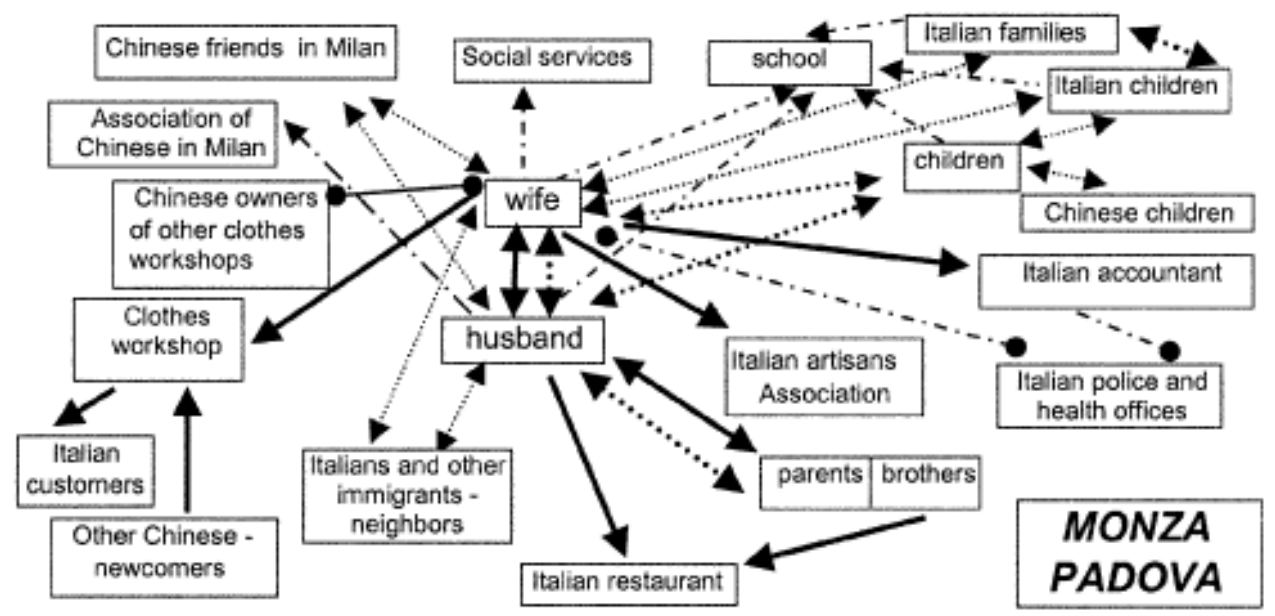

Unbroken line = economic tie

Small dots line $=$ informal social tie (expressive)

Stroke-dot line $=$ formal social tie (institutional)

Edge $=$ direction of the relation

Arrow = cooperative relation

Small ball = competitive relation (conflict)

Thickness (unbroken line) $=$ degree of confidence

Thickness (small dots line) = degree of (inter) dependence

More immediate chances of improving their living conditions have to be found by the parents. For example, it can be more convenient to work for Italian restaurants in which one earns more than in Chinese ones. In fact, when the communitarian ties are looser, exploitation can replace solidarity. In some cases, it is not easy to distinguish between exploitation and solidarity or common rules. That is to say that the newcomers have to pay back relatives or friends who gave illegal immigrants' traffickers money for their transfer. Therefore, newcomers are considered as low-cost workers for a long time, even longer than the time necessary to pay back their debt.

If these problems, or other kind of economic problems (for example, Italian firms that delay payment for a very long time, or don't pay at all because they go bankrupt) occur, the Chinese entrepreneurs can ask for the help of their bookkeepers or, as is recently becoming more and more common, they can become members of the Artisans association, which will take care of their interests. For non-economic problems, another possibility is to get in touch with the social services. Especially in the health care systems, Chinese (mostly women) who ask to be treated are constantly growing in number, while in the past even health was a matter taken care of inside the community.

The difficulties that Chinese immigrants have had to face in these last years have increased their dependency on Italian institutions. This has increased the awareness of some institutions (like school or the health care system) about the Chinese problems and needs. More and more often, organizations or individuals are acting as brokers for this ethnic community, whose presence is better tolerated from the Italians in Monza Padova (and other peripheral areas) than in Canonica Sarpi. Different situations mighted bring about diverging results : while the healthier Chinese, living and working in Canonica Sarpi, will continue to rely on and live within the ethnic community and economic system, the more disadvantaged ones will increase their expectations on 
their children, but will also seek immediate help and improvement outside the community.

\section{Two individual strategies}

Having showed the general pattern of social network in Chinese community in the ' $80 \mathrm{~s}$ and explained the transformations that occurred in the "90s with the growth of the group and the decline of the traditional economical sectors, I am now going to describe and compare two ego-networks.

51 In the first one, a young man, owner of a clothes manufacture and of an import export company, has established many weak ties outside the ethnic network, even though the focus of his economic activities and social life remains the in-group. The success of the family is the success of the individual, as shown by graph. 5 .

Graph. 5 : Network of FW

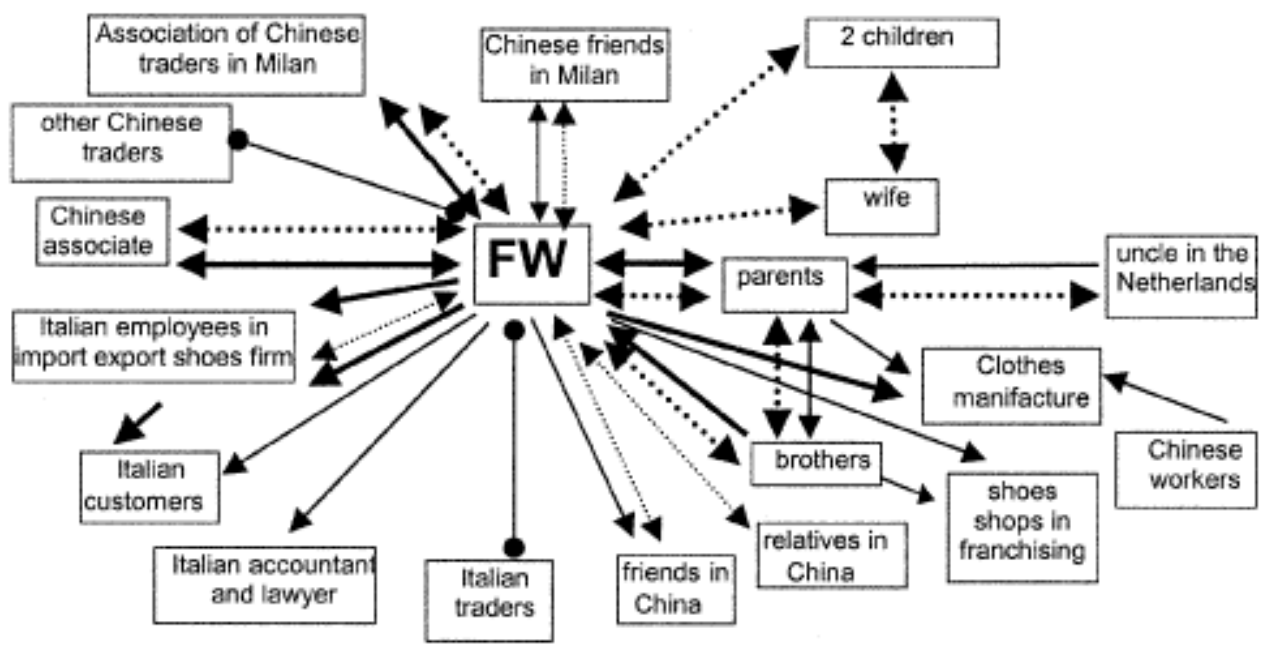

Unbroken line = economic tie

Small dots line $=$ informal social tie (expressive)

Stroke-dot line $=$ formal social tie (institutional)

Edge $=$ direction of the relation

Arrow $=$ cooperative relation

Small ball = competitive relation (conflict)

Thickness (unbroken line) = degree of confidence

Thickness (small dots line) $=$ degree of (inter) dependance

This person, FW, arrived in Milan in 1993, when his father could request legal permission for the rest of the family to enter Italy. He was 15 , so he had been educated in Chinese schools. He speaks Italian quite well. His parents managed to have their own clothes manufacture, but thanks to his linguistic skills, intelligence and ability to build and maintain influent friendships both in Italy and China, he is, at the age of 24 , the owner of a medium size import export company which trades all over Europe and is opening a chain of franchised shops for his younger brothers. His ability for creating guanxi and the awareness of their importance have lead him to employ Italians assistants in order to be better considered by Italian customers and to be closer to the Italian taste. 

vice-president. Even if the Association is not very representative (only 21 members), they try to offer a lot of services and to mediate conflicts among Chinese traders and with Italians.

54 friendly relationship with one of his assistant, who speaks Chinese and has lived in the Far East for a certain time.

His desire of success is obvious in many details : apart from his clothes and car, he has chosen a private school for his children, a school that is considered very exclusive, even for most of the Italian population.

The other person is a woman aged 42. WX arrived in Milan after having lived some years in France and in Bari (where she arrived in 1986). In Milan, she had an uncle and other distant relatives. After having worked for a few years for an Italian clothes manufacturer, and with the financial help of relatives and friends, she managed to start a clothes workshop. Now, she employs 4 workers, all of them relatives and friends, and has a single Italian customer. Other Chinese work for the same customer, who is quite big and reliable, so there is not a lot of competition among the Chinese : everybody has enough work to do and each business is so small that they couldn't do more than they actually do. Future prospects are not so good, both because of her low degree of selfconfidence and the hard economical conditions that limit her profits possibilities.

Her network is less dense than that of FW and she has multiple relations only with relatives and friends who work for her and with her relatives in China, to whom she regularly sends money. Her relations with other members of the community are positive, but rare. She works so much that she has no time for social life. Her position among her relatives and close friends network is not as important as it is FW case. Anyway, she has a more central role in the firm than her husband, who only helps her occasionally. He is the one who takes care of the children, so she hasn't got very close connexion with them. But still, her hopes for a better future concern mainly her children. For her, it is very important that they become like Italians. WX has been in Italy longer than FW, but she hasn't reached the same economic success. She has acquired a very stable position, but she has focused more on working hard than in creating useful relations. She doesn't participate in social meetings with other members of the community, and her isolation limits the opportunities that she could have to improve her situation. 


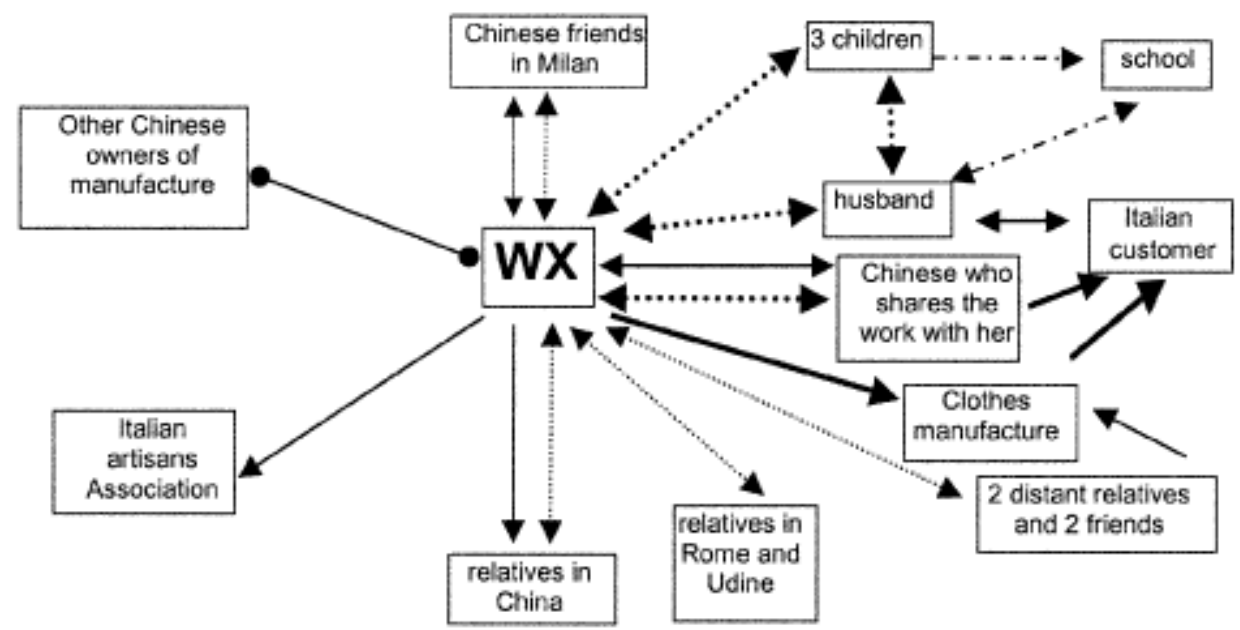

Unbroken line = economic tie

Small dots line $=$ informal social tie (expressive)

Stroke-dot line $=$ formal social tie (institutional)

Edge $=$ direction of the relation

Arrow $=$ cooperative relation

Small ball = competitive relation (conflict)

Thickness (unbroken line) $=$ degree of confidence

Thickness (small dots line) $=$ degree of $($ inter $)$ dependance

Concerning her links to Italians, she has a quite close relation with the Artisans Association. She goes there very often, but it's only an instrumental tie, like the one with the customer. She is one of the few people interviewed who speaks highly of her customer, whom she trusts a lot. Unfortunately, these two links are not enough to let her have a chance of improvement outside the ethnic community.

These networks confirm the theory of Lin (2001) : strong ties are mainly expressive and weak ties are usually instrumental. This could be true considering Lin's proposal that there is no clearcut difference, but only a trend. In fact, among Chinese immigrants, strong ties are very often also instrumental, so in this case it would be better to say that strong ties can be both expressive and instrumental, while weak ties are only instrumental. As the family is the main actor in the individual career, it's very likely that members of the family share some kind of economic interest, but not all of them. The tendency suggested by Lin is more obvious in WX's network, while in the case of $\mathrm{FW}$, there is a higher use of strong ties not only in an expressive, but also in an instrumental way.

\section{Conclusion}

Many network properties can be useful to explain the different paths toward economic and social integration.

61 First, the strength of ties is relevant to understand the role of the family, close friends and the rest of the ethnic community in contributing to the achievement of their goals by immigrants : they are primarily related to the acquisition of the entrepreneurial status. 
and more people have arrived and all kinds of ages are represented in town. This has increased the relations with social services and institutions like schools, which are considered very important by Chinese parents. The integration process is still far from being completed, but in some areas of the town, living together with other ethnic groups and the local population is easier than for other groups. Moreover, every person can handle his/her social networks in different ways in order to achieve his/her goals. Some seek their personal achievement mainly within the community, while others choose, or are forced to build, more ties with the local population and institutions in order to improve their living conditions.

\section{BIBLIOGRAPHY}

BERTI Fabio (2000) Esclusione e integrazione. Uno studio su due comunità di immigrati Milano, Franco Angeli, $240 \mathrm{p}$.

BOISSEVAIN Jeremy (1974) Friends of friends Oxford, Basil Blackwell, 285 p.

CAMPANI Giovanna, CARCHEDI Francesco, TASSINARI Alberto (eds.) (1994) L'immigrazione silenziosa. Le comunità cinesi in Italia, Torino, Fondazione Giovanni Agnelli, 235 p.

CECCAGNO Antonella (ed.) (1997) Il caso delle comunità cinesi. Comunicazione interculturale ed istituzioni Roma, Armando, $222 \mathrm{p}$.

CECCAGNO Antonella (1998) Cinesi d'Italia, Roma, Manifestolibri, 155 p.

CHIESI Antonio, ZUCCHETTI Eugenio (2003) Immigrati imprenditori, Milano, Egea, 310 p.

COLEMAN James (1990) Foundations of Social Theory, Belknap Press Harvard University Press, 321 p. COLOGNA Daniele (2002a) La Cina sotto casa, Milano, Franco Angeli, 96 p.

COLOGNA Daniele (2002b) Bambini e famiglie cinesi a Milano, Milano, Franco Angeli, 112 p.

COLOGNA Daniele e MANCINI Letizia (2000) Inserimento socio-economico e percezione dei diritti di cittadinanza degli immigrati cinesi a Milano, Sociologia del diritto, 3, 48 p.

Revue européenne des migrations internationales, vol. 20 - $n^{\circ} 3$ | 2004 
FARINA P., COLOGNA D., LANZANI A., BREVIGLIERI L. (1997) La Cina a Milano. Famiglie, ambienti e lavori della popolazione cinese a Milano, Collana AIM - Editoriale Abitare Segesta.

FERNANDEZ Marilyn e KIM Kwang Chung (1998) Self-employment rates of Asian immigrants groups : an analysis of intragroup and intergroup differences, International Migration Review, 32, pp. 654-679.

FREEMAN Linton (2000) Social network analysis : definition and history in KAZDAN, A.E. (ed.) Encyclophedia of Psychology, Oxford University Press, 6, pp. 350-351.

GOULD Roger e FERNANDEZ Roberto (1989) Structures of mediation : a formal approach to brokerage in transaction networks, Sociological methodology, 19 pp. 89-126.

GRANOVETTER Mark (1973) The strength of weak ties, American Journal of Sociology, 78, pp. $1360-1380$

GRANOVETTER Mark (1974) Getting a job, Harvard University Press, pp. 41-62 in PISELLI Fortunata (ed.) Reti. L'analisi di network nelle scienze sociali, Donzelli, 1995.

GRIECO, Margaret (1987) Keeping it in the family Tavistock Publications pp. 71-96 in PISELLI Fortunata (ed.) Reti. L'analisi di network nelle scienze sociali, Donzelli, 1995.

KADUSHIN Charles (2002) The motivational foundation of social networks, Social networks, 24, pp. 77-91.

LIN Nan (2001) Social capital, Cambridge University Press, 278 p.

MA MUNG Emmanuel (1992) Economic organization and spatial resources : elements of the economy of the Diaspora, Revue Européenne des Migrations Internationales, 8 (3), pp. 175-194.

MARSDEN Peter e LIN Nan (eds.) (1982) Social structure and network analysis, Beverly Hills, Sage Publications, $319 \mathrm{p}$.

MURER Bruno (2001) La paura di Babilonia. IX aggiornamento sull'immigrazione, Ufficio stranieri di Milano, $43 \mathrm{p}$.

PISELLI Fortunata (ed.) (1995) Reti. L'analisi di network nelle scienze sociali, Roma, Donzelli, 334 p.

PORTES Alejandro e SENSENBRENNER Julia (1993) Embeddedness and immigration : notes on the social determinants of economic action, American Journal of Sociology, 98, pp. 1 320-50.

VAN POUCKE Willy (1978-79) Network constraints on social action : preliminary for a network theory, Social Networks, 2, pp. 181-190.

www.milano.istruzione.lombardia.it/auton/scuole/progaut.htm Un approccio integrato all'inserimento scolastico e l'integrazione socio-culturale degli alunni cinesi.

www.chinatownitalia.com Ou A. La storia delle Associazioni cinesi a Milano e in Italia.

\section{NOTES}

1. In fact, Egyptian worked for Italians before starting their own firm, in which not only Egyptian work but also people from other nationalities (Italians included). On the other hand, Chinese entrepreneurs used to work mainly for other Chinese and their workers now are all Chinese.

2. This committee, named Vivisarpi, is composed by Italians living in the area Canonica-Sarpi and is active since 2000. The members complain about the difficult cohabitation with chinese, especially the import-export shops. The latter are accused of creating problems to the road 
conditions because of the big trucks that often come to bring goods. Moreover, Chinese are also considered too far from Italian culture and difficult to communicate with.

3. Nodes in the network that share the same pattern of links and, for this reason, are interchangeable, are considered structural equivalent.

4. Ethnic firms are defined as enterprises that use ethnic networks for start-up capital, reliable low-wage labour and, eventually, a market for culturally defined goods (Portes \& Sensenbrenner, 1993).

5. Source : Lombardia Region.

6. In this area were living, in 2000, 1603 Chinese, highly concentrated in a few streets.

7. Most of the Chinese living in this area comes from the villages around Yuhu, a small town in Zhejiang province.

\section{ABSTRACTS}

The aim of this work is to give a theoretical and methodological contribution to the use of networks in migration studies. Strength of ties, multiplicity, density, expressive and instrumental links, cooperative and competitive relations are important concepts to analyse the transformations of the Chinese community in Milan. In the ' 80 s the community was dense and cohesive and it was easy for newcomers to improve their economic status, while in the '90s the situation has gradually become worse. The first "Chinese area", Canonica Sarpi, has turned into a service area, bringing as a consequence the concentration of the newcomers in more peripheral areas, such as Monza Padova. In these two areas, there are various levels of integration and different kinds of conflicts with the Italians. Moreover, everyone manipulates his/her network in dissimilar ways in order to reach economic and social integration, and some achieve these goals faster than others also thanks to their network.

Les réseaux de la communauté chinoise à Milan. Cet article se propose de contribuer au débat sur l'utilisation de la problématique des réseaux dans la sociologie des migrations. La force des liens, la multiplicité, la densité, les relations de coopération et de compétition etc. sont des concepts importants pour analyser les changements dans la communauté chinoise à Milan. Alors que dans les années 1980 les migrants avaient plus d'opportunités d'améliorer leur situation économique, les nouveaux arrivants des années 1990 rencontrent plus de difficultés. À Milan, on trouve d'une part le vieux quartier Chinois Canonica Sarpi, qui est devenu le centre commercial et social et d'autre part des zones de résidence à la périphérie de la ville, comme Monza Padova peuplée de nouveaux arrivés Dans ces deux quartiers, les formes d'intégration et la nature des conflits avec les Italiens sont différentes. En outre les uns et les autres se servent de leurs réseaux de relations en vue d'une intégration sociale et économique, mais tous n'y réussissent pas de façon identique.

Las redes de la comunidad china de Milán. Este artículo se propone contribuir al debate sobre el tratamiento que la sociología de las migraciones otorga a la problemática de las redes. La fuerza de los lazos, la multiplicidad, la densidad, las relaciones de cooperación y de competición, etc. son conceptos importantes en el análisis de los cambios en la comunidad china de Milán. Si en los años 80 los emigrantes gozaban de oportunidades para mejorar su situación económica, en los años 90, los recién llegados se topan con mayores dificultades. En Milán podemos identificar, 
en primer lugar, el barrio chino antiguo de Canonica Sarpi, hoy centro comercial y social y, en segundo lugar, zonas residenciales situadas en la periferia de la ciudad y, como es el caso de Monzo Padova, pobladas de recién llegados. Las formas de integración y la naturaleza de los conflictos con los italianos son diferentes en cada uno de los dos barrios. Unos y otros utilizan sus redes de relaciones con vistas a la integración social y económica, pero no todos lo logran de la misma manera.

\section{INDEX}

Mots-clés: insertion sociale, réseaux communautaires Geographical index: Italie

\section{AUTHOR}

\section{DEBORAH DE LUCA}

Post-Doc Fellow, Dept. Sociology and Social Research, University of Trento, Via Verdi 2638100 Trento 